\title{
CONNECTING LEGEND AND SCIENCE THROUGH GEOMYTHOLOGY: CASE OF LANGKAWI UNESCO GLOBAL GEOPARK
}

\author{
Tanot Unjah $^{1^{*}}$ and Sharina Abdul Halim ${ }^{2}$ \\ ${ }^{1}$ Langkawi Research Centre (PPL), Kedah, MALAYSIA \\ ${ }^{2}$ Institute for Environment and Development (LESTARI), Universiti Kebangsaan \\ Malaysia, MALAYSIA \\ *Corresponding author: tanot-u@ukm.edu.my
}

Published online: 29 December 2017

To cite this article: Tanot Unjah and Sharina Abdul Halim. 2017. Connecting legend and science through geomythology: Case of Langkawi UNESCO global geopark. Kajian Malaysia 35(Supp.1): 77-89. https://doi.org/10.21315/km2017.35.Supp.1.5

To link to this article: https://doi.org/10.21315/km2017.35.Supp.1.5

\begin{abstract}
Integrating scientific and cultural knowledge is pivotal in the conservation of a geopark. Using case study from the Langkawi UNESCO Global Geopark, the main aim of this article is to discuss the connection between scientific aspects of geological landscape and myths, legends and folklore in the area (or also known as geomythology). Langkawi's geological landscape comprises five key rock formations known as Machincang, Setul, Singa, Chuping and igneous rock of Gunung Raya. Each formation consists of exposed rock diversity that resulted from tectonic activity and weathering process caused by waves and surface runoff water. Langkawi's geological landscapes are bestowed with distinctive rock diversity that hold within them mysterious legends, myths and folklore, in which connect local communities with landscapes. Among the well-known geomythology, or legends associated within these geological landscapes, are Gunung Machinchang, Gunung Raya and Belanga Pecah (Battle of the Giants of Mat Chinchang and Mat Raya), Gua Cherita (Legend of The Roman Emperor's Son and mythical giant bird) and Pulau Dayang Bunting (Tale of A Pregnant Maiden). The interpretation of landscape from a scientific perspective together with cultural knowledge has revealed an intrinsic link between geology and its people. In a sense, geomythology carries great significance to geopark development, not only for conservation purpose but it also serves as a means to boost local tourism that can in turn facilitate the local socio-economic development of the island.
\end{abstract}

Keywords: heritage, integrated interpretation, geosites, knowledge tourism, Langkawi geopark 


\section{INTRODUCTION}

Research has shown that there are many outstanding geological heritage in Malaysia that have been lost or compromised due to natural or development processes. For instance, records of exceptional landforms have been documented, unfortunately these landforms remain only in the written form, as the physical manifestation of such geological heritage no longer exists on site (Aw, 1977). Furthermore, Ibrahim and Kadderi (1989) noted in their work on geotourism in Langkawi Island that numerous sites of outstanding geological features have been demolished during the development of the island. Although concerted efforts have been carried out to address these challenges (Mohd. Shafeea et al., 2007), more work is needed to minimise the loss of these outstanding geological features. This would include strengthening the understanding of geological importance, particularly among developers and relevant stakeholders, conducting rigorous systematic studies in identifying outstanding geological features throughout the country and making better connections between geological resources and livelihoods in the context of everyday lives.

According to Tangherlini (1990), legend and local folklore can be defined as traditional stories that are related to human nature, their ancestors or warriors, and meant to explain various aspects of ordinary life. More often than not, this connection between legend, local folklore and daily lives is so close that the local community has included this connection in their daily lives through various medium as an attempt to explain their natural environment, such as in place naming of roads, hills, and mountains (Lias, 1991; Rahimah and Ong, 2011; Gwynn, 2016; Vitaliano, 2007) as well as agricultural practices (Lugeri et al., 2011). In geology, the explanation of connection between landscape, either obvious or obscure, active natural phenomena, such as earthquakes, volcanic and floods, and local myths are known as geomythology (Vitaliano, 2007). Geomythology has proven to be helpful in solving geological problems on the ground, as well as highlighting the basis of certain geological nomenclature that are also associated with local myths and folklore.

This article will discuss aspects related to conservation and custodianship using the approach of geomythology from the perspective of legends and myths in Langkawi Island, and their connection with the landscape of the area. Geomythology has the potential to strengthen the critical need to protect these natural landscapes as well as to increase local appreciation towards landscapes in that area. In addition, it can improve ways to impart scientific and cultural knowledge as part of the areas' attraction for public and tourists' consumption to the island in an effort to minimise the impact of rapid development. 


\section{GEOLOGICAL LANDSCAPE OF LANGKAWI}

The landscape diversity in Langkawi Island is significantly linked to the type of rock diversity that formed it (Mohd Shafeea et al., 2007). The rock diversity in Langkawi consists of four sedimentary and one igneous rock. The sedimentary rock is represented by two clastic and two carbonate rocks. All of these rocks diversity that are distributed throughout the island (Figure 1) emerged during the Triassic period, and have since reacted differently to the meteoric water and sea level changes in the island. In terms of heritage, each of this rock diversity is influenced by various environmental conditions and impacts and they differ according to their chemical content and nature of formation. Ibrahim (2003) described the geological landscape as an assemblage of landforms that is not just visually outstanding, but equally important, it contains high intrinsic value that can be associated with the origin of the landform and nature of the materials, in which form the landscape and

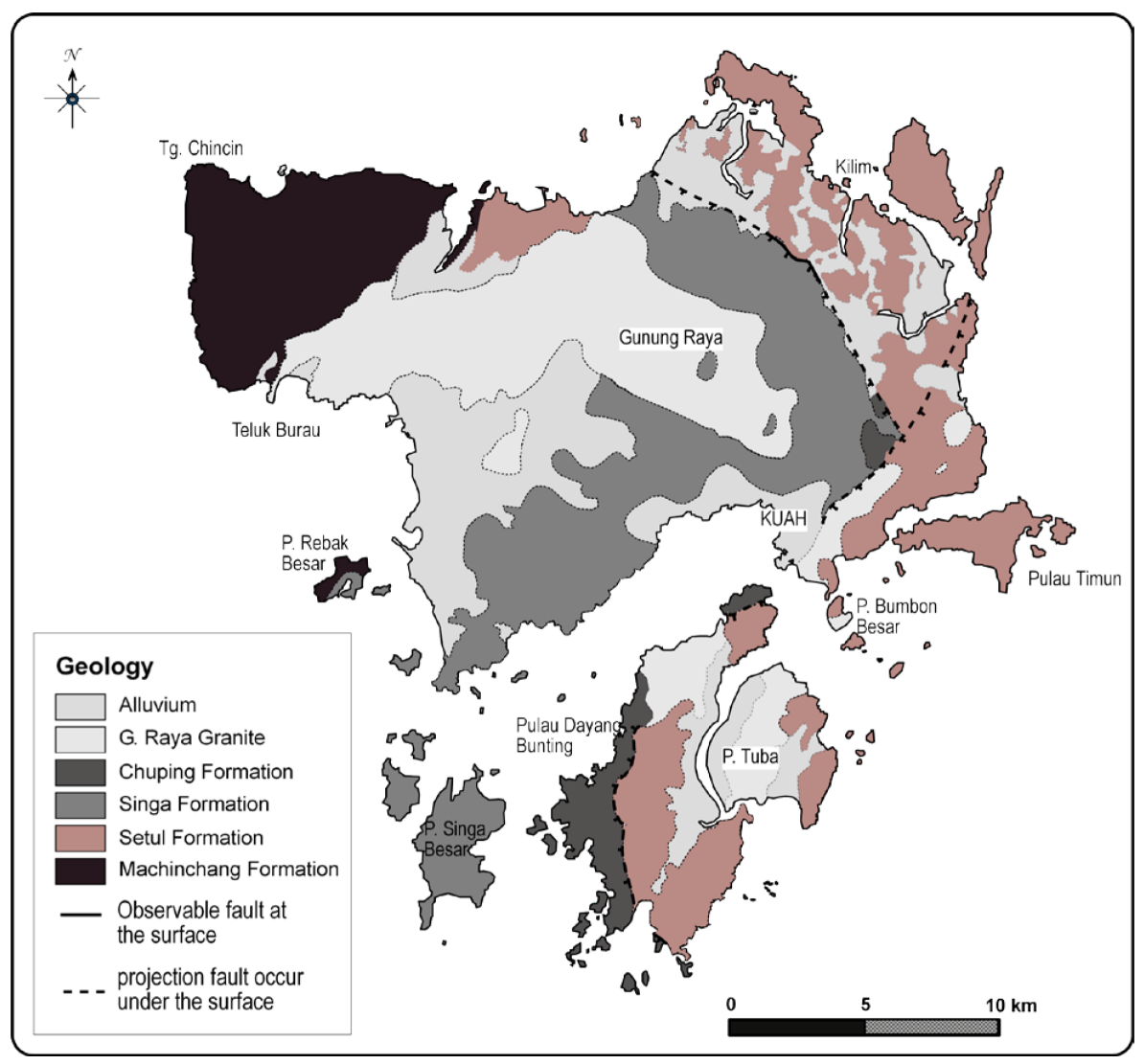

Figure 1: Geological or rock distribution in Langkawi Island (modified after Jones, 1981 and Mohd Shafeea et al., 2007). 
natural processes that are responsible for crafting its current shape. As well, the temporal evolution which makes it unique in time and space.

A brief description of various types of rocks and their geological landscape in Langkawi is as follows:

\section{Clastic Sedimentary Rock}

Clastic sedimentary rock consists of the Machinchang Formation and Singa Formation. The Machinchang Formation is the oldest clastic sedimentary rock at the age of 550 million years old and this rock formation has been exposed to a series of tectonic events such as folding and faults before being exposed to weathering in Trias. According to the studies on the Machinchang Formation, the features within the rock confirmed the origin of sediment deposited at shallow sea to a lacustrine (river) environment. Owing to active tectonic movement during the Triassic and Pre Jurassic periods, this layered rock has been through three major deformations to form anticline and syncline, later folded and lastly tilted to its current position (Ibrahim, Kamal Roslan and Che Aziz, 1997; Tjia, 1989). These processes leave various patterns that include symmetrical cuts along the layer and folded structure by stress, strain and pressure (Figure 2).

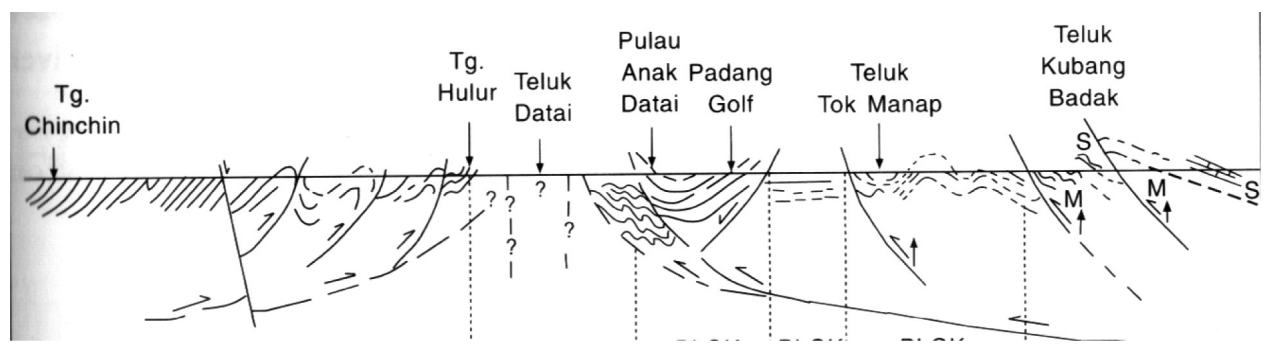

Figure 2: The structure interpretation at the northern part of Machinchang Formation, modified from Ibrahim, Kamal Roslan and Che Aziz (1997).

Some of the cuts also extend to a fault as process to stabilise the landscape, create a distinct gap known as graben and horst. This landscape which is later subjected to weathering and erosion, can be observed as a series of low and high rock steep, cone-like shape and elongated mountain. The combination of these various shapes is referred to as hogback mountain. Meanwhile, another clastic sedimentary rock, known as the Singa Formation age 360 million years old, is made of mudstone and fine grain sandstone deposited on the continental slope. The deposition environment near the continental shelf which is known to be unstable causes part of the layered formation to become overburdened. Thus, fall and crumble within it creates a feature known as turbidites. This type of sedimentary rock is 
slightly soft in nature and easily eroded by tropical weathering. Therefore, this rock creates a low-land hill with a height between $50 \mathrm{~m}$ to $200 \mathrm{~m}$. Only some parts of the rock are slightly harder than others due to dynamothermal metamorphism during the Triassic period, particularly those that are close to the igneous body.

\section{Carbonate Sedimentary rock}

Carbonate sedimentary rock is formed at the continental shelf in warm water conditions, and in Langkawi it is represented by two different ages, at 490 million years old and 286 million years old. Although both the depositions were created by similar environment, differences occurred due to the influence of current during deposition. The differences can be observed in the composition and colour of the limestone (Che Aziz et al., 2005; Meor Hakif et al., 2013). The 490 million years old formation known as the Setul Formation, is deposited at both shallow and deep marine elements with more mud due to sea level changes while the 286 million years old, or Chuping Formation, was deposited at the shallow environment with less mud. Thus, Setul Formation is darker or muddier compared to Chuping Formation, which is of white and fair limestone. The geological landscape of limestone is often signified by a towering hill with rounded top or mogote, a cone shape hill or a flat top with medium slope and at Langkawi these hills range from $20 \mathrm{~m}$ to $100 \mathrm{~m}$ (Jones, 1981; Mohd Shafeea, 2003; Kamal Roslan, Mohd Shafeea and Che Aziz, 2004, Unjah and Ibrahim, 2005). The weathering by meteoric or rain water and sea waves shape this landscape dramatically with various vertical cliffs, sea notches, dolines, caves, sharp pinnacles and sea stakes as well as isolated island.

\section{Igneous Rock}

The only igneous rock in Langkawi is 245 million years old and known as the Gunung Raya Igneous (Bignell and Snelling, 1977; Jones, 1981). This igneous intrusion was also the main factor that lifted the whole island to the surface and exposed them to the weathering process. The nature of igneous rock with more interconnected mineral gives it more resistance toward weathering compared to the surrounding rocks. The highest peak in the highland is situated within this rock at $880 \mathrm{~m}$ in height. Igneous hills in Langkawi are often symmetrical with rounded top and gentle slope.

The recent sediment consists of alluvium deposit along the coast and the low land area were evidence of wide estuaries at the mouth of large rives and by narrow sea straits, indicating submerged former river valley (Tjia, 1989; Raj, 2009). The submerged river valley later covered by beach deposit until the sea level changes left this area as an ancient depositional terrace located several feet from current sea level (Jones, 1981). 


\section{GEOMYTHOLOGY OF LANGKAWI}

Geomythology or connection between legend and geological landscape of Langkawi UNESCO Geopark are discussed based on oral documentation, published material as well as field observation of the landscape in Langkawi. Four selected well-known legends namely, Tasik Dayang Bunting (Lake of Pregnant Maiden), Telaga Tujuh (Seven Wells), Gua Cherita (Cave of Legendary Stories), and Mat Chinchang and Mat Raya (Battle of The Giants) on the island are studied, after taking into consideration availability of supporting materials, with detailed scientific description.

\section{Tasik Dayang Bunting}

According to Mohammad Shahidan (1994), Tasik Dayang Bunting or Lake of Pregnant Maiden is based on the famous legend of the ill-fated love story of Mambang Sari, a beautiful female spirit and Mat Teja (a male djinn). Mambang Sari and her maids love to play at the cove called Teluk Lawak. One day, as he was passing through, Mat Teja caught a glimpse of Mambang Sari and was struck by her beauty that he instantaneously fell passionately in love. Fearing his love might not be reciprocated, he sought the advice of a local sage known as Tok Dian. He advised Mat Teja, that in order to win Mambang Sari's heart, he needed to wipe his face with the tears of a mermaid.

After following the instruction diligently, Mat Teja swiftly pursued the love of his life and when Mambang Sari saw him she fell in love immediately, and before long they were happily married. During her pregnancy, Mambang Sari sojourned at a serene lake, known as Tasik Dayang Bunting. Soon it was time for Mambang Sari to give birth but the baby died seven days later. In intense sorrow, she laid the body to rest in a deep lake. It is believed that the baby turned into a mythical white crocodile. Since then, villagers have associated the lake with having magical or healing powers. They believed that the lake's water possessed a mystical power to heal barren women. It is said that Mambang Sari, overflown with maternal affection and distressed at such a fortuity, blessed the waters that any woman who is unable to conceive, will be rewarded with a child if she drinks the water from the lake.

From the geological point of view, this lake is formed by an accumulation of water from an underground river at the control river mouth. In this case the control river mouth is a $10 \mathrm{~m}$ thick limestone with several cracks underground that transmits the water from the lake to the sea and receives or is intruded by sea water. Thus, the water at this lake is slightly brackish in taste. Besides that, the soluble limestone causes the water to have natural alkalinity commonly found in rocks containing carbonate, bicarbonate and hydroxide compounds. According to the 
measurement by the Department of Mineral and Geoscience (2001), the oval lake is $800 \mathrm{~m}$ in length and $350 \mathrm{~m}$ wide and a side sonar scan has identified the maximum depth lying at $14 \mathrm{~m}$ (Figure 3).

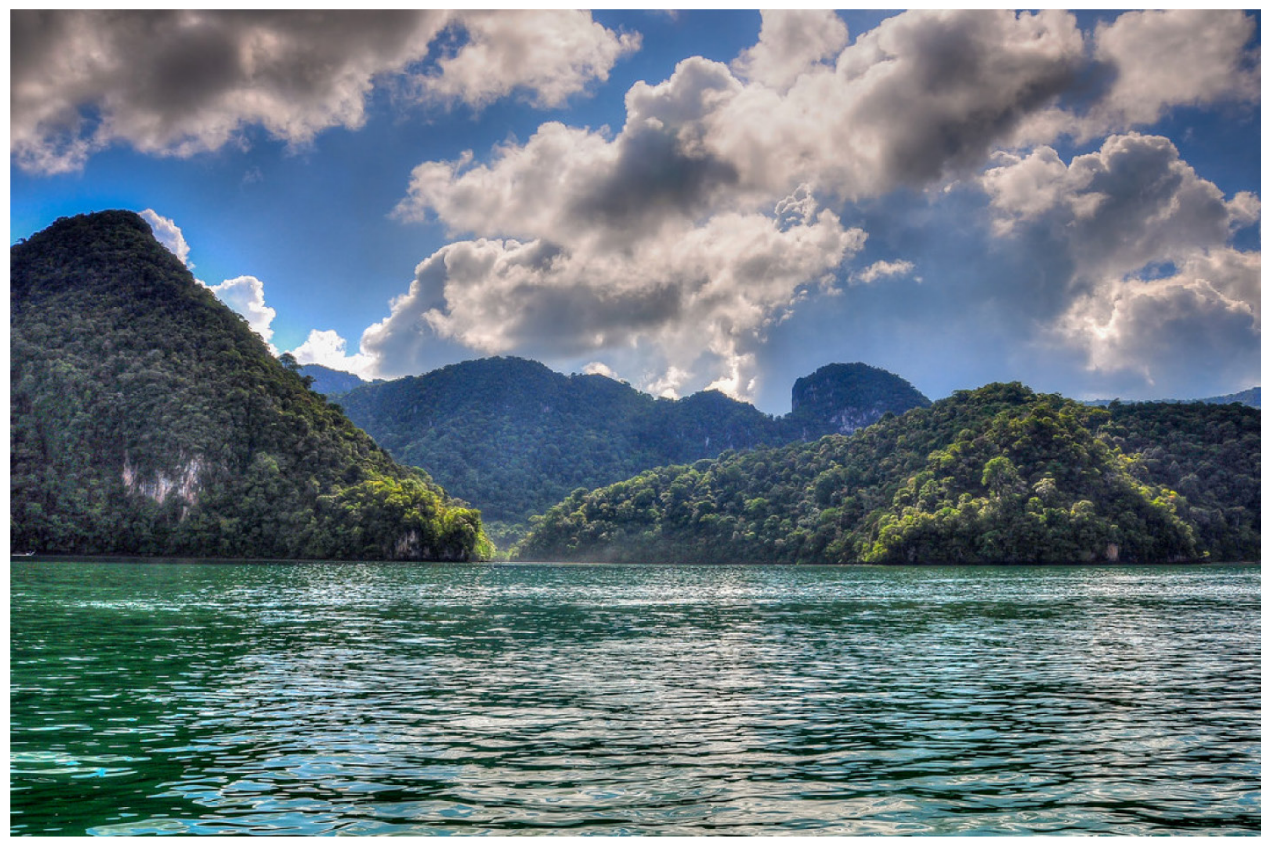

Figure 3: The figure of lying pregnant lady at Tasik Dayang Bunting, formed by series of mogotes and rounded hills with steep slope. Picture by Khairul Amri Marhalim.

The landform in this area is formed by rain water and running water dissolving on limestone rock. The whole landscape is a common doline feature formed by a collapsed cave cover on top of the lake due to the dissolving limestone wall. The remnants of the crater left by the collapse continues to be eroded by rain water to form a towering hill with rounded top called mogote, with a slight cone and some with a sharp peak called pinnacle. A combination of rounded, cone-like and sharp peaks of this white limestone with little plant on top, create the famous profile of a lying pregnant lady associated with the legend of a pregnant maiden when observed from afar.

\section{Telaga Tujuh}

The name Telaga Tujuh or the Seven Wells is derived from the seven natural pools from the uppermost to lowest pools, in which are linked by small streams found along Sungai Burau (Figure 4). The pools along with a waterfall are located deep 
in the forest and locals believed that it is a place where forest spirits and djinns dwell. The popular belief is that seven beautiful ethereal maidens would bathe in the pools during the night but they would vanish into thin air if any human attempts try to get near. Thus, people who head to the waterfall are cautioned to observe the local "do's and don'ts" lest they anger the inhabitants.

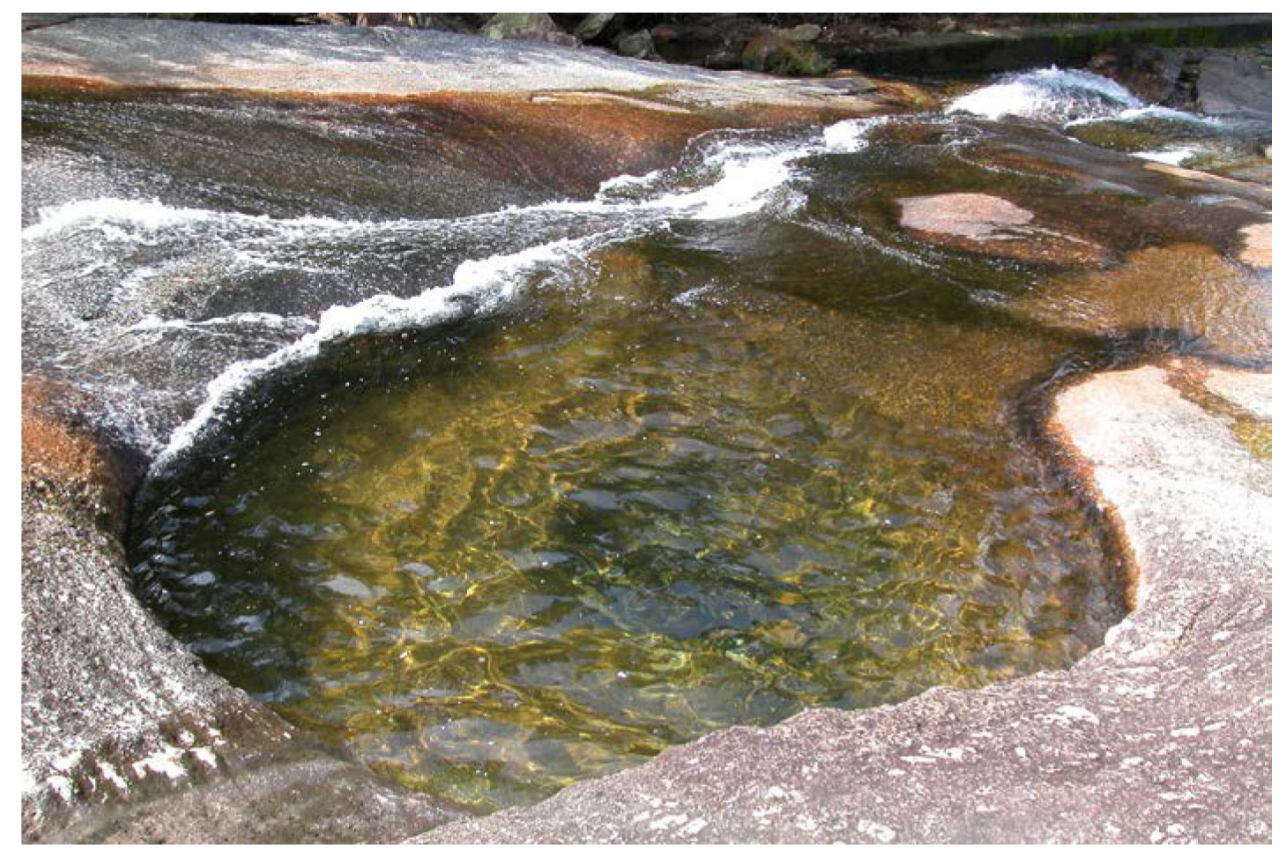

Figure 4: One of the fairy pool at the upper part of the Telaga Tujuh Waterfall naturally this pool is created by the swirling pebble that act like a screw that bore the granite rock.

The geological landscape of Telaga Tujuh is a common feature, formed along a moving water with a gap of height created by fault movement that created a series of pot holes and waterfall. Flowing water formed the seven potholes at the upstream moving pebbles within it until it accumulated and became like a screw to bore the rock. Several potholes are only active during the rainy season when water flows through the pot holes and move the pebbles, filling it with green algae during the dry season. The location of the potholes which is along the flow of the water includes the overflow area during the rainy season and diameters ranged from $1.5 \mathrm{~m}$ to $5 \mathrm{~m}$ with depth from $30 \mathrm{~cm}$ to $1.5 \mathrm{~m}$. In this area, the rock is easily eroded at its weakest point, mainly at the boundary of contact between granite and sedimentary rock, to form the waterfall and river. Geologists consider the rock boundary observed along the waterfall to be one of the best sample of its kind (Mohd Shafeea et al., 2007; Jones, 1981). 


\section{Gua Cherita}

Gua Cherita, or the cave of legendary stories, derived its name from the legend of Merong Mahawangsa who was assigned to escort the son of a Roman Emperor to China in a sea voyage. The entire fleet including the ship carrying the prince was said to have been sunk by a mythical Phoenix. The prince was washed ashore and that the legend took place in the cave of legends.

According to the mythology of the voyage of Raja Merong Mahawangsa, the great empires of Rome and China were considered the mightiest powers in the world in the 10th AD. To ensure continuity of great powers, the rulers of these two empires agreed to a marriage between their children. Their plan was to foster a closer alliance, which was not favoured by the mythical fire bird or the phoenix. The phoenix believed the coalition between Rome and China would signify the end of small kingdoms. The phoenix was against the union and abducted the daughter of the Chinese Emperor and hid her in a palace on the isle of Langkawi.

During the relentless attacks from the phoenix, Merong Mahawangsa turned one of his arrows into Jentayu, the mythical bird, endowed with the power to call the rain, which was no match for the mighty phoenix. Defeated, Merong Mahawangsa ordered his fleet to seek shelter at the nearby island so that repairs on the damaged fleet could be carried out. As they set their journey and crossed the waters of Langkawi, the phoenix returned and swooped on one of the ships where the Roman Prince happened to be in. The prince fell into the sea and washed ashore onto a beach in Langkawi. The beach was close to the palace where the Chinese Emperor's daughter was hidden. One of the princess' maids found the Prince and alerted the Princess. They carried him back to the palace and revived him. When the story of his journey to China to marry the princess was unveiled, the Princess hid him in a cave away from the phoenix that frequented the island.

Gua Cherita is a limestone cave formed due to solutioning of the weak zones within the rock to create an opening that grew bigger through time. Located at the northern part of the island, this area directly faced the sea and is also exposed to the sea erosion leaving evidence as sea noches. According to Kamal Roslan, Mohd Shafeea and Che Aziz (2004), Gua Cherita consists of two caves located $18 \mathrm{~m}$ above sea level while the other one at approximately $1.5 \mathrm{~m}$ from the current sea level. The upper cave has a smaller opening that grows larger inside the cave. Stalactites and stalagmites are the common features formed by the solutioning and accumulation of carbonate deposit. In this area, both the stalactite and stalagmite are already cojoined to form a tall pillar. However, some parts of the flat surface of a stalagmite are still retained, creating a bed- like feature which is often referred to as the Chinese princess' bed. Meanwhile, the second cave located at the bottom was formed by the wave's erosion during 2000 years ago when the sea level was $1.5 \mathrm{~m}$ above the current sea level. 


\section{Mat Chincang and Mat Raya}

The famous myth of Langkawi is based on three mountains that were once humans who were turned or cursed into their present forms. Mat Chinchang and Mat Raya who were sparring partners were trained by the same mentor in the martial art of self-defence. One day they had a fight but the fight was stopped by Mat Sawar or Mat Sabar, their martial art member. Another story related this fight to a grudge they had with each other which was made worse when they were about to become in-laws. During the wedding of their respective son and daughter, a minor issue caused a fight between them.

The fight was brutal as it messed up the wedding and the wedding preparations. The soaked rice, broken pots, gravy, boil water and even the wedding ring were scattered throughout the island. The fight also frightened all living things on the island, including a lion, a snake and a water buffalo, that they escaped to the main island in the southern area. All the items and the animals were preserved in the form of places called Tanjung Chinchin (ring headland), Belanga Pechah (broken pot), Ayer Hangat (hot water), Pulau Singa (lion island), Pulau Ular (snake island), Kubang Darat and Kubang Laut (representing the place where water buffaloes wallow).

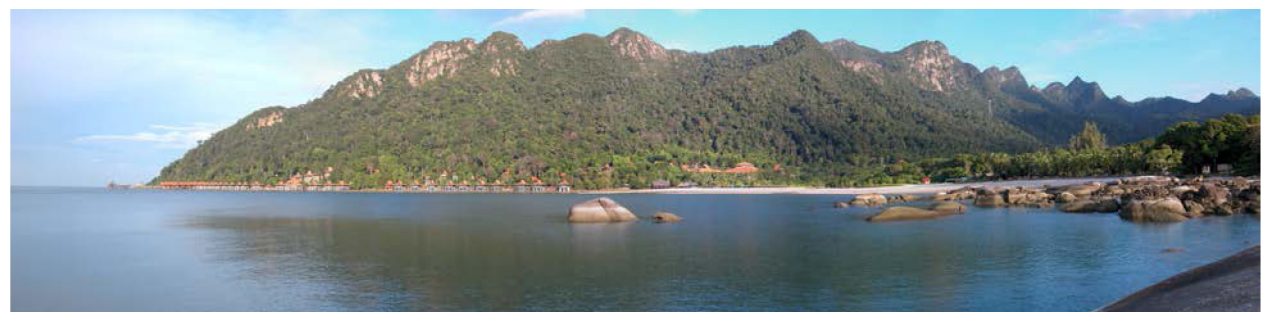

Figure 5: The slice like peak of Mount Machinchang is the differential weathering by weather in the tropical country along the weak zone or cut and perhaps that indicates that Mat Chinchang really get a great blow during the fight.

Geologically, the mounts of Gunung Machinchang, Gunung Raya and Bukit Sawar are the most prominent relief on the island with a height below $850 \mathrm{~m}$. Gunung Machinchang made from sandstone rock is 550 million years old while Gunung Raya and Bukit Sawak formed from granite rock aged 280 million years old. Gunung Machinchang being the older rock has endured movements such as folds and faults that broke the rock into cubicle like shapes, as observed at the top of Machinchang. An intrusion by granite pushed the folded rock to tilt to the northeast. Meanwhile, the granite rock intruded into the existing rock, pushing them up at the same time, and burying them under the soil until active tropical weathering exposed them to light. The rock formation and the weathering left a 
sliced-like mountain of Gunung Machinchang and majestic symmetrical mountain form of Gunung Raya (Figure 5).

Geologically, the fold and fault were due to tectonic movement recorded in the region known as the Kisap Thrust Fault and also a series of normal fault that followed suit. Fault zones or where the main movement took place often cause the rock to be crushed to pieces and in Langkawi they are just like pieces from a broken pot. The best field evidence can be observed at Belanga Pechah. Most of the fault lies deep inside the crack with a possibility of reaching to the deeper earth. Thus, all the water that seeps through and later released to the surface tends to be warmer or hotter than normal temperature and in the case of Langkawi, this can be observed at the Ayer Hangat Hot Spring. Folds on the other hand, cracked the layered and left numerous patterns on the rock particularly the older one. In the case of Langkawi the symmetrical fold is like a well-formed shank of a ring at Tanjung Chinchin.

The mountains of Langkawi surrounding the lowland are formed by mudstone with a height up to approximately $100 \mathrm{~m}$ and the much lower plain is formed by sand ridges left by lowering sea levels or along the main river alluvium area. Areas such as Ulu Melaka, Pantai Chenang, Pantai Tengah and Kuah town sit in this part of the lower plain and alluvium area.

\section{CONCLUSION}

Research and field observations have recognised a connection between geological landscape and local culture particularly through myths and legend in Langkawi. In this article, the connection between myths and legend and geological formation are mostly derived from larger-scale landscape. Most of the main landscapes represent the main features of geology, geological event and weathering control in the areas. However, evidence or connection of geological features, geological events and weathering control on a smaller-scale, particularly landforms and geological feature, will need further study.

Understanding the connection between landscape and local myths and legends in Langkawi opens the opportunity to link geological, biological and cultural as part of knowledge-based tourism. There is now a need to engage the custodians of this cultural repository, to link their knowledge, their stories and the importance they attach to specific areas to the unique geological heritage that exists. This is vital in the development of tourism within geopark areas to encourage the understanding of heritage in an integrated way. Besides, it adds depth and perspective to allow tourists to appreciate the natural beauty from the lens of myths and legends. 
On the other hand, establishing connections also provide us a better understanding of human connection with their environment particularly landscape or physical environment. Although this article only discusses part of the benefits of connection, there are other aspects that should be looked at, for instance from the psychological point of view and health benefits. This is one of the many steps to be taken in linking the science of geological heritage with human dimension. Through these small measures, this linkage can provide policy makers and those with the task to carry out development, as well as the public a better way of understanding their environment, in order to act effectively in protecting and conserving these landscapes or areas. This will ensure that the locals will benefit and subsequently put them on a path for a sustainable livelihood.

\section{REFERENCES}

Aw, P. C. 1977. Potential conservation area of geological interest. Geological Survey Department. Report no G2/1977.

Bignell, J. D. and N. J. Snelling. 1977. Geochronology of the Malaysian granite. Overseas Geology and Mineral Resources 47: 72.

Che Aziz Ali, Kamal Roslan Mohamed, Ibrahim Abdullah and Mohd Shafeea Leman. 2005. Mikrofasies dan diagenesis di dalam batu kapur Formasi Setul di kawasan sekitar Kilim, Langkawi. In Culture and nature heritage of Langkawi-Kilim Basin, eds. Mohd Shafeea Leman, Ibrahim Komoo, A. Latif and Hood Salleh, 171-183. Bangi: LESTARI, Universiti Kebangsaan Malaysia.

Gwynn, E. 2016. Exploring geological language in the Welsh Landscape. Earth Heritage 5 December.

Ibrahim Abdullah, Kamal Roslan Mohamed and Che Aziz Ali. 1997. Geology of the Machinchang Formation. In Geological heritage of Malaysia-Conservation geology for ecotourism, eds. Ibrahim Komoo, Mohd Shafeea Leman, Kadderi Md Desa and Ibrahim Abdullah, 149-168. Bangi: LESTARI UKM.

Ibrahim Komoo. 2003. Conservation geology: Protecting hidden treasures of Malaysia. ASM Inaugural Lectures. Bangi: Penerbit LESTARI UKM.

. 2000. Conservation geology: A multidisciplinary approach in utilisation of earth resources without distruction. Proceeding Geological Society Malaysia 3-12.

. 1998. Geologi pemuliharaan. In Sekalung budi setitis tinta - Festchrift Profesor Sham Sani, ed. Mazlan Othman, 43-52. Bangi: Penerbit UKM.

Ibrahim Komoo and Kadderi Md Desa. 1989. Kepulauan Langkawi: Bahan dan bentuk bumi sebagai sumber pembangunan pelancongan. Seminar Pembangunan Pelancongan Langkawi: Sejarah Alam Semulajadi, Tanjung Rhu, Langkawi, Kedah. 27-28 September.

Ibrahim Komoo and Mazlan Othman. 2002. The classification and assessment of geological landscape for nature conservation. Proceeding International Association for Engineering Geology (IAEG), Durban, South Africa, 1117-1123. 
Jones, C. R. 1981. Geology and mineral resources of Perlis, North Kedah and Langkawi Islands. Geological Survey of Malaysia District Memoir 17: 257.

Kamal Roslan Mohamed, Mohd Shafeea Leman and Che Aziz Ali. 2004. Warisan Kars Kilim, Langkawi, Malaysia. In Warisan geologi di Indonesia dan Malaysia, eds. Sutarto, Suparto, Herwan Lukito, Heru Sigit and Mohd Shafeea Leman, 285-298. Yogyarkata: Universitas Pembangunan Nasional "Veteran" Indonesia.

Lias, A. 1991. Place names of the Welsh Borderlands. USA: Palmers Press.

Lugeri, F. R., V. Amadio, A. Cardillo, R. Bagnaia and N. Lugeri. 2011. Landscapes and wine production areas: A geomorphological heritage. Geoheritage 3: 221-232. https://doi.org/10.1007/s12371-011-0035-z.

Meor Hakif Amir Hassan, B. S. Yeow, C. P. Lee and Abdul Hadi Abdul Rahman. 2013. Facies analysis of the uppermost Kubang Pasu Formation, Perlis: A wave-and storm-influenced coastal depositional system. Sains Malaysiana 42(8): 10911100 .

Mohd Shafeea Leman. 2003. Karstic hills of the Setul Limestone in Kilim Valley, Langkawi, Malaysia. In Culture and science of mountains, eds. Hood Salleh, Mazlan Othman, Ibrahim Komoo and Sarah Aziz, 175-185. Bangi: Penerbit LESTARI UKM.

Mohd Shafeea Leman, Kamarulzaman A. Ghani, Ibrahim Komoo and Norhayati Ahmad, eds. 2007. Langkawi Geopark. Bangi: Penerbit LESTARI UKM and Langkawi Development Authority (LADA).

Mohammad Shahidan. 1994. Koleksi terpilih cerita rakyat Malaysia. Kuala Lumpur: Dewan Bahasa dan Pustaka.

Panizza, M. and S. Piacente. 2005. Geomorphosites: A bridge between scientific research, cultural integration and artistic suggestion Geomorphological sites and geodiversity. Il Quaternario-Italian J. Q. Science 18: 3-10.

Rahimah Abdul Aziz and Ong Puay Liu. 2011. Placemaking, place names, and local myths and legends. Planning Malaysia 9(Special issue): 145-158.

Raj, J. K. 2009. Geomorphology. In Geology of Peninsular Malaysia, eds. C. S. Hutchinson and D. N. K. Tan, 5-28. Kuala Lumpur: Geological Society of Malaysia.

Tangherlini, T. R. 1990. It happened not too far from here: A survey of legend theory and characterization. Western Folklore 49(4): 371-390. https://doi. org/10.2307/1499751.

Unjah, T. and Ibrahim Komoo. 2005. Characterization of Kilim Valley karst landscape: A study based on horizontal view. In Culture and nature heritage of Langkawi-Kilim Basin, eds. Mohd. Shafeea Leman, Ibrahim Komoo, A. Latiff and Hood Salleh, 199-210. Bangi: Penerbit LESTARI UKM.

Tjia, H. D. 1989. Structural geology of Datai beds and Machinchang formation, Langkawi. Bulletin of Geological Society Malaysia 23: 85-120.

Vitaliano, D. B. 2007. Geomythology: Geological origins of myths and legends. In Myth and geology, eds. L. Picarrdi and W. B. Messe. Geological Society of London, Special Publication, 273, 1-7. http://sp.lyellcollection.org/content/273/1/1 (accessed 3 May 2017). 